\title{
A Study of Chinese College Students' English Listening Strategies
}

\author{
Zhang Bei \\ School of Foreign Languages \\ University of Jinan, Jinan City, China \\ Shao Xinguang \\ School of Foreign Languages \\ University of Jinan, Jinan City, China
}

\begin{abstract}
This study investigates how Chinese college students apply English Listening strategies with questionnaires. The findings show that Chinese college students don't do well in applying many English listening strategies, especially the metacognitive strategy of making plans, the cognitive strategy of inference and the social strategy of cooperation. Most students need to improve themselves in applying listening strategies so as to enhance their listening abilities. In English listening teaching, teachers should try to integrate the training of listening strategies into the normal classroom English teaching.
\end{abstract}

Keywords: Chinese college students, English Listening strategies, questionnaires, training

\section{INTRODUCTION}

Listening is an important way of learning English for Chinese learners. Their improvement in listening ability can help them to enhance their abilities in other aspects, especially in speaking and writing. But it is very difficult for Chinese students to improve their English listening abilities because the skills in listening comprehension are hard to be mastered. Many Chinese students' low ability in listening comprehension seriously affects their overall development in English learning. So it is extremely necessary for English teachers to adopt some effective methods to train the listening strategies of their students. Some experts have studied the learners' listening strategies in foreign language learning and it has been accepted that the training of listening strategies can really improve foreign language learners' listening abilities and cultivate their awareness of using strategies (O'Malley, etc. 1989; Herron, etc. 1991).

\section{LITERATURE REVIEW}

The process of listening comprehension is not only a language decoding process but also a significance reconstruction process. So language comprehension is a dynamic process in which people should use all kinds of strategies to decode language information that they hear. In this process, listeners should have active participation so as to get good understanding of the message they have got. Richards (1990) thinks listening comprehension involves a bottom-up process and a top-down process. The bottom-up process refers to the listeners' use of their language knowledge like the meanings of some words and the rules of some sentences to understand the information. The top-down process means the listeners' use of their background knowledge to understand the listening materials. In both of the two processes, listeners do need to apply some strategies to help them do better in listening. 
According to Anderson (1983), the listening process involves three steps: perception, parsing and utilization. In the three steps of listening, a learner may use some strategies unintentionally like memory strategy, choice strategy and guessing strategy to help him grasp the meaning of the information that he has got.

Psycholinguistics (Scovel, 2000) may provide us with an insight into the nature of listening comprehension. People do not often process linguistic information in a direct and simple way. More often than not, people may use much background information to help them comprehend the linguistic information they have heard. Listening comprehension is a dynamic process in searching for those related information in people's background knowledge. For instance, when people comprehend a sentence, some related structures may influence the garden path that they follow in the comprehension process. If listeners follow a wrong garden path in the listening process of a sentence, they may be likely to have some misunderstandings.

Some experts have got many achievements in the field of learning strategies and listening strategies. In the eye of Oxford (1989), learning strategies are learners' behaviors that they take in their language learning. Those behaviors can make language learning become more successful and more enjoyable. He thinks learning strategies include direct strategies and indirect strategies, both of which consist of some concrete cognitive and other strategies.

O'Malley and Chamot (1990) make very careful research about learning strategies. According to them, learning strategies are some procedures that the learners take in order to make their foreign language learning become more efficient. Their category of learning strategies includes metacognitive strategies, cognitive strategies, social and affective strategies. Metacognitive strategies may be used to help foreign language learners manage their study well, including thinking about the process of study, making learning plans, monitoring learning tasks, evaluating learning results, etc. Cognitive strategies are those methods applied by learners to directly control their language information so as to get the new language knowledge. These cognitive strategies mainly include association, induction, inference and so on. Social and affective strategies refer to foreign language learners' cooperation with other people in order to get more chances of using language and adjusting their moods in their learning process. These strategies may help the learners improve their self-confidence and overcome their anxiety in foreign language learning.

Some experts have already studied the effect of using some strategies on students' listening levels. O'Malley etc. (1989) think the medium level ESL students may be classified into the "effective group" and the "ineffective group". It has been found that the students in the "effective group" are more efficient in using the strategies like self-monitoring, elaboration and inference and that many foreign language learners' listening levels are closely connected with their utilization of strategies.

In China, there are some experts who have also made some researches about listening strategies used by Chinese learners of English. One expert named Wen Qiufang (1996) discovers that students' differences in using listening strategies have an important influence on their English learning, leading to their different learning results.

In the field of listening strategy training, some experts have got important findings. Herron and Seay (1991) find that the learning results of the students who have got the training of strategies are much better than the students who do not. It is also found that the strategy training may greatly improve students' listening ability. Some experts find that listening 
strategy training is welcomed by many students and it should be integrated into foreign language classroom teaching. ( Nunan, 1996; Su, 2002)

\section{RESEARCH REPORT}

In this part, the researcher analyzes Chinese college students' use of English listening strategies with the help of questionnaires.

\section{Research Purpose}

The purpose of this study is to investigate the main listening strategies that Chinese college students like to use and find out the main reasons. The findings of this study can help these learners to improve their English listening abilities.

\section{Subjects}

The subjects in the investigation are all freshmen in the University of Jinan in China. Their majors are Finance, Management and Physics. The subjects are 160 students including 86 boys and 74 girls. They range in age from 17 to 20, with an average age of 18.5. All the students have learned English for more than 9 years.

\section{Instrument}

Questionnaires are used to investigate the subjects' use of English listening strategies. The items are made by the researcher based on the classification of listening strategies given by O'Malley and Chamot (1990). The 15 items are about some metacognitive strategies, cognitive strategies and social/ affective strategies.

For the subjects to get their scores in the 15 items about English listening strategies, each item is on a 5-point scale ranging from "strongly agree" (point 5) to "strongly disagree" (point 1), the middle point being neutral (point 3). The higher a subject scores in an item, the more likely he/she is to use the relevant English listening strategy.

\section{Data Collection}

On September 26 of 2014, 160 questionnaires were distributed to the subjects. They were asked to finish the questionnaires within 10 minutes. After they finished, all the questionnaires were collected and all the copies were found to be valid.

\section{Results and Analysis}

In order to find out how Chinese college students use English listening strategies, the researcher adopted the method of analyzing the means of the subjects' scores in the items.

Table 1 shows the means of the subjects' scores in the 15 items. 
Table 1

\begin{tabular}{|l|l|l|}
\hline Items & $\begin{array}{l}\text { Numbers } \\
\text { of the } \\
\text { subjects }\end{array}$ & $\begin{array}{l}\text { Means of } \\
\text { the } \\
\text { subjects' } \\
\text { scores }\end{array}$ \\
\hline Item 1 & 160 & 2.45 \\
\hline Item 2 & 160 & 2.16 \\
\hline Item 3 & 160 & 3.78 \\
\hline Item 4 & 160 & 2.62 \\
\hline Item 5 & 160 & 4.26 \\
\hline Item 6 & 160 & 3.75 \\
\hline Item 7 & 160 & 2.88 \\
\hline Item 8 & 160 & 3.94 \\
\hline Item 9 & 160 & 3.67 \\
\hline Item 10 & 160 & 3.35 \\
\hline Item 11 & 160 & 4.19 \\
\hline Item 12 & 160 & 2.37 \\
\hline
\end{tabular}

The metacognitive listening strategies are included in items 1-4. Item 1 is "In college English learning, I often make a good plan for my listening practice." $(\mathrm{M}=2.45)$. Item 2 is "Besides English listening exercises in class, I often do some listening practices after class and I can monitor myself in these exercises." $(M=2.16)$. Item 3 is "I may change my listening methods if I find they can not improve my English learning." $(M=3.78)$. Item 4 is "I spend some time practicing English listening everyday." (M=2.62). As can be seen, the subjects' means of scores in three items about metacognitive listening strategies are all below 3.0. From the statistics it can be seen that students don't do well in using metacognitive listening strategies. There are not many students who can make their plans for English listening and practice listening after class everyday. Most students can change their listening methods when necessary, which is a 
good point. But generally the metacognitive strategies are not often used in the students' doing English listening exercises.

The cognitive strategies are described in items 5-11. Item 5 "I often think about the main idea of a passage when listening to it according to some topic sentences." (M=4.26). Item 6 is "In the listening process, I always pay much attention to some specific language points such as names and numbers." (M=3.75). Item 7 is "I like to infer the meanings of the new words in some contexts, trying not to look them up in the dictionary." (M=2.88). Item 8 is "When listening to an English passage, I make use of the related culture background knowledge to help me understand it." $(\mathrm{M}=3.94)$. Item 9 is "In the listening process, I always try to grasp the meanings of some unfamiliar words according to the collocations of the words and other familiar words." $(\mathrm{M}=3.67)$. Item10 is "When listening to some difficult English sentences, I like to translate the sentences into Chinese to help me understand them better." (M=3.35). Item11 is "I make full use of my knowledge of the world and common sense to help me understand English passages better when listening to them." (M=4.19). It can be seen that many students can use some cognitive strategies such as translation and trying to grasp the particular points in their English listening. Most students like to guess the main ideas of English passages according to some topic sentences, which is a good thing. But many subjects' scores in Item 7 are below 3.0, which indicates that many students can not often apply the cognitive strategy of inference in listening exercises. In fact, inference is a very useful listening strategy that may help Chinese learners a lot when they meet some unfamiliar words in English passages. So they need to train themselves in using the listening strategy of inference.

The social and affective strategies are included in items 12-15. Item 12 is "When listening to a passage, I often write down the difficult expressions that I don't understand and discuss them with the teachers and the classmates." (M=2.37). Item 13 is "I always encourage me to have confidence in myself and try to make progress in my English listening." (M=2.96). Item 14 is "When I can not do well in English listening exercises, I may encourage myself not to lose my heart." (M=3.15). Item 15 is "I often communicate with my teachers and classmates in English after class to improve my English listening ability." (M=2.53). As can be seen, the subjects' means of scores in three items about social and affective strategies are below 3.0. So it is clear that many students don't do well in using the social and affective strategies in listening exercises. Although many students can encourage themselves not to lose their hearts, they haven't realized the importance of communicating with their teachers and classmates in English after class. It seems that many Chinese students haven't cultivated the good habit of cooperating with other people in English learning. They need to improve themselves in cooperation with others, which may offer them many good opportunities of practicing English.

\section{PEDAGOGICAL IMPLICATIONS}

Based on the statistics of the research, there are some pedagogical implications. Generally speaking, most students need to cultivate their sense of applying listening strategies in English learning, because many Chinese students can't do well in applying listening strategies, especially some metacognitive strategies and social strategies. Therefore, teachers should help them by integrating the listening strategy training into the classroom English teaching. They may tell the students the importance of using listening strategies in English learning and clarify how to use these strategies in specific situations. In daily English teaching, teachers should provide the students with many chances of using listening strategies so that they can cultivate their sense of applying strategies. What's more, they may ask their students to evaluate the 
advantages of using different listening strategies so that they may have a deep understanding of these strategies.

In carrying out the training of listening strategies, teachers must try to help their students improve the ability of using metacognitive strategies. Most students ignore the importance of these strategies, so they do not have the habit of making their plans for English listening learning and they may gradually lose confidence in it. Teachers should help them develop their interest in English listening learning. They may do some things to achieve this goal like letting their students listen to some good English songs and speeches.

It is widely accepted that most students have their own weak points in listening comprehension. Therefore, teachers should help their students to find out these weak points in order to help them apply some useful strategies to improve themselves in this aspect. They may also help the students to set up different goals according to their actual situations so that the students can motivate themselves to do better in English listening. Teachers should guide their students to regularly have self-evaluation about their English listening situations. In this way, students can know better about their English listening abilities and then try their utmost to make progress.

It is a key point to train students to utilize cognitive strategies in English listening exercises. Although many students can use some cognitive strategies like translation, there are still a lot of students who are not good at applying the strategies of inference and elaboration which are very important in doing listening exercises. Teachers should encourage their students to use these cognitive strategies often. If they can master these good skills, doing listening exercises will become much easier for them.

Applying social and affective strategies is also very significant in doing English listening exercises. The strategies such as psychological adjustment, cooperation and self-talk may greatly enhance the students' proficiency of English listening.

In the viewpoints of O'Malley and Chamot (1990), strategy training must be integrated into language teaching. Strategy teaching must be direct so that foreign language learners may have a deep understanding of the application of different strategies. After making great efforts in many researches, they design a cognitive academic language learning approach (CALLA) which includes 5 stages: the preparation phase, the presentation phase, the practice phase, the evaluation phase and the expansion phase. As is known to all, knowledge of the strategies is declarative knowledge at first, but it may gradually be changed into procedural knowledge after long-time practice. It is hoped that Chinese college students may improve their English listening abilities by using strategies appropriately.

\section{CONCLUSION}

The training of listening strategies is very important in Chinese college English teaching. It may help many college students improve their listening abilities. Proper use of some listening strategies may help these students overcome their difficulties in doing English listening exercises, making them become more confident. It is hoped that Chinese college teachers should adopt some good and effective teaching methods in their English listening teaching based on their students' actual situations. They should try to strengthen the training of listening strategies and help their students grasp the strategies that are suitable for themselves. What is the most important is to try every means to stimulate their students' interest in English listening and foster their learning awareness and enthusiasm so as to 
improve their listening abilities. All in all, the training of listening strategies should become an important part in English listening teaching.

\section{Bibliography}

1. Anderson, J. R. The Architecture of Cognition. Cambridge, Mass.: Harvard University Press, 1983.

2. Herron, C \& I. Seay. The effect of authentic aural texts on student listening comprehension in the foreign language classroom. Foreign Language Annals, 1991, (24): 487-495.

3. Nunan, D. Learner strategy training in the classroom: an action research study. TESOL Journal, 1996, 6 (1): 35-41.

4. O'Malley, J., A. Chamot, and L. Kupper. Listening comprehension strategies in second language acquisition. Applied Linguistics, 1989, 10 (4): 418-437.

5. O’Malley, J. \& A. Chamot. Learning Strategies in Second Language Acquisition. Cambridge: Cambridge University Press, 1990.

6. Oxford, R. Use of language learning strategies: a synthesis of studies with implications for teacher training. System, 1989, (17) : 235-247.

7. Richards, J. C. The Language Teaching Matrix. Cambridge: Cambridge University Press, 1990.

8. Scovel, T. Psycholinguistics. Shanghai: Shanghai Foreign Language Education Press, 2000.

9. $\mathrm{Su}, \mathrm{Y}$. L. How to conduct the training of listening strategies. Computer-assisted Foreign Language Education in China, 2002, (3): 8-12.

10. Wen, Q. F. On English Learning Strategies. Shanghai: Shanghai Foreign Language Education Press, 1996.

\section{APPENDIX}

Chinese College Students' English Listening Strategy Scale Based on the classification of listening strategies given by O'Malley and Chamot (1990), a questionnaire "Chinese College Students' English Listening strategy Scale" is designed by the researcher in order to investigate students' general use of English listening strategies. The results of the survey are only used in the study of English teaching and learning.

Items 1-15 are about your feelings when you do English listening exercises. Please choose the number after each item, which may embody your true condition concerning the item. The five numbers 1-5 after each item stands for "extremely disagree", "disagree", "uncertainty", "agree", "extremely agree" respectively.

Thanks for your cooperation!

1. In college English learning, I often make a good plan for my listening practice. [1] [2] [3] [4] [5]

2. Besides English listening exercises in class, I often do some listening practices after class and I can monitor myself in these exercises.

[1] [2] [3] [4] [5]

3. I may change my listening methods if I find they can not improve my English learning. [1] [2] [3] [4] [5]

4. I spend some time practicing English listening everyday.

[1] [2] [3] [4] [5]

5. I often think about the main idea of a passage when listening to it according to some topic sentences.

[1] [2] [3] [4] [5]

6. In the listening process, I always pay much attention to some specific language points such as names and numbers. 
[1] [2] [3] [4] [5]

7. I like to infer the meanings of the new words in some contexts, trying not to look them up in the dictionary.

[1] [2] [3] [4] [5]

8. When listening to an English passage, I make use of the related culture background knowledge to help me understand it.

[1] [2] [3] [4] [5]

9. In the listening process, I always try to grasp the meanings of some unfamiliar words according to the collocations of the words and other familiar words.

[1] [2] [3] [4] [5]

10. When listening to some difficult English sentences, I like to translate the sentences into Chinese to help me understand them better.

[1] [2] [3] [4] [5]

11. I make full use of my knowledge of the world and common sense to help me understand English passages better when listening to them.

[1] [2] [3] [4] [5]

12. When listening to a passage, I often write down the difficult expressions that I don't understand and discuss them with the teachers and the classmates.

[1] [2] [3] [4] [5]

13. I always encourage me to have confidence in myself and try to make progress in my English listening.

[1] [2] [3] [4] [5]

14. When I can not do well in English listening exercises, I may encourage myself not to lose my heart.

[1] [2] [3] [4] [5]

15. I often communicate with my teachers and classmates in English after class to improve my English listening ability.

[1] [2] [3] [4] [5] 